\title{
ANALISIS NILAI ESTETIS KERAJINAN MINIATUR KAPAL PADA PENGRAJIN KRIYA ASMIDAR DI MEDAN PERJUANGAN
}

\author{
Dailami Tanjung $^{*}$, Azmi $^{2^{*}}$, Tetty Mirwa ${ }^{3 *}$, Triyanto $^{4 *}$ \\ Program Studi Pendidikan Seni Rupa Jurusan Seni Rupa Fakultas Bahasa dan Seni \\ Universitas Negeri Medan \\ Jl. Willem Iskandar Pasar V Medan Estate, Kec, Percut Sei Tuan, Kab. Deli Serdang, Kode Pos 20371 \\ Sumatera Utara. Indonesia \\ Email: dailamitanjung@gmail.com
}

\begin{abstract}
Abstrak
Penelitian ini di latar belakangi untuk mendeskripsikan nilai estetis pada kerajinan miniatur kapal pada pengrajin kriya Asmidar Di Medan Perjuangan. Pembatasan masalah dalam penelitian ini berfokus pada penerapan nilai estetis dan hasil karya kerajinan miniatur kapal pada pengrajin kriya Asmidar di Medan Perjuangan. Populasi dalam penelitian ini yaitu seluruh kerajinan miniatur kapal pada pengrajin kriya Asmidar. Dalam penelitian ini penulis mengambil teknik sampling jenuh, yaitu teknik penentuan sampel bila semua anggota populasi digunakan sebagai sampel sebanyak 8 karya kerajinan miniatur kapal. Dalam hal ini penulis akan meneliti karya kerajinan miniatur kapal tersebut berdasarkan aspek proporsi, keseimbangan, kesatuan, dan finishing. Adapun metode yang digunakan dalam penelitian ini adalah metode deskriftif kualitatif. Berdasarkan data yang telah diperoleh, maka semua hasil penilaian dari ke dua ahli secara keseluruhan pada kerajinan miniatur kapal karya pengerajin Kriya Asmidar ditinjau berdasarkan aspek proporsi, keseimbangan, kesatuan, dan finishing, secara umum dikategorikan baik dengan jumlah nilai $=703$ dan rata-rata $(r)=88$ (baik).
\end{abstract}

Kata Kunci: analisis, kerajinan, miniatur kapal.

\begin{abstract}
This research is in the background to describe the aesthetic value of miniature craft shipments at the craftsmen of Asmidar craft in Medan Perjuangan. The problem limitation in this study focuses on the application of aesthetic values and the work of ship miniature crafts to the craftsmen of Asmidar craft in Medan Perjuangan. The population in this study is all miniature craft of craft in the craft of the Asmidar craft. In this study the author takes a saturated sampling technique, which is a sample determination technique if all members of the population are used as a sample of 8 ship miniature craft works. In this case the author will examine the ship's miniature craft based on aspects of proportion, balance, unity and finishing. The method used in this research is qualitative descriptive method. Based on the data that has been obtained, all the results of the assessment of the two experts as a whole on the miniature craft of the work of the craftsmen Kriya Asmidar are reviewed based on the aspects of proportion, balance, unity, and finishing, generally categorized as good with a number of values $=703$ and average $(r)=88($ good $)$.
\end{abstract}

Keywords: analysis, crafts, miniature's ship.

\section{PENDAHULUAN}

Kerajinan miniatur merupakan kerajinan seni 3D berukuran kecil yang mengutamakan unsur keindahan di dalamnya. Pada saat sekarang ini kerajinan miniatur sangatlah beragam, salah satunya adalah miniatur berbentuk kapal layar berbahan kulit bambu dan kertas. Produk kerajinan miniatur kapal layar ini sangat banyak diminati oleh masyarakat di kota Medan. Saat ini kerajinan miniatur kapal layar sering digunakan untuk mengisi dekorasi ruang tamu, kantor dan rumah tangga, selanjutnya dapat juga dijadikan sebagai cendramata (souvenir). Miniatur kapal layar ini lazim menirukan kapal layar Pinisi Nusantara berdasarkan bentuk. Pengrajin kriya Asmidar berlokasi di Jalan Ibrahim Umar Medan Perjuangan. pengrajin kriya Asmidar merupakan salah satu pengrajin yang usahanya khusus dibidang pembuatan miniatur kapal layar. Berdasarkan hasil observasi awal yang dilakukan oleh penulis melalui wawancara dengan pengrajin kriya Asmidar di Medan Perjuangan mengatakan bahwa permintaan pasar terhadap produk miniatur kapal layar sangat beragam. Salah satunya adalah pengrajin harus pandai menawarkan kreasi kapal layar dari berbagai macam bahan alternativ yang 


\author{
Gorga Jurnal Seni Rupa \\ Volume 07 Nomor 02 \\ p-ISSN: 2301-5942 | e-ISSN: 2580-2380
}

mudah di dapat agar permintaan pasar tetap terpenuhi. Penggunaan bahan baku kulit bambu dan kertas dapat menjadi alternatif yang dapat digunakan pengrajin karena bahan tersebut mudah dijumpai dilokasi pengrajin.

Berdasarkan pengamatan yang dilakukan, penulis melihat bahwa masih banyak kerajinan miniatur kapal layar yang proses akhirnya belum maksimal. Hal itu dikarenakan, kurangnya kerapian dan kehalusan dalam pembuatan karya kerajinan miniatur kapal. Selain itu, bahan baku yang dipakai tidak bervariasi menyebabkan produk kerajinan miniatur kapal yang dibuat pengerajinan kurang menarik perhatian konsumen. Yang menjadi faktor utama adalah pengrajin kurang memikirkan dan menerapkan nilai estetis dalam pembuatan karya kerajinan miniatur kapal sehingga, mempengaruhi keindahan miniatur kapal itu sendiri.

Berdasarkan latar belakang masalah yang telah diuraikan., maka dapat dibuat identifikasi masalah sebagai berikut: Permintaan pasar terhadap produk miniatur kapal layar sangat beragam. Kurangnya kerapian dan kehalusan dalam pembuatan karya kerajinan miniatur kapal. Bahan baku yang dipakai untuk pembuatan karya kerajinan miniatur kapal tidak bervariasi. Pengrajin kurang memikirkan dan menerapkan nilai estetis dalam pembuatan karya kerajinan miniatur kapal. Dari beberapa identifikasi masalah penulis membuat batasan atau fokus masalah yang dapat mempertegas penelitian ini, batasan masalah penelitian ini adalah: penerapan nilai estetis dan hasil karya kerajinan miniatur kapal pada pengrajin kriya Asmidar di Medan Perjuangan.

Berdasarkan pembatasan masalah di atas, maka yang menjadi rumusan masalah dalam penelitian ini adalah: Bagaimana hasil karya kerajinan miniatur kapal pada pengrajin kriya Asmidar di Medan Perjuangan?

Bagaimana penerapan nilai estetis pada karya kerajinan miniatur kapal pada pengrajin kriya Asmidar di Medan Perjuangan?

Berdasarkan rumusan masalah diatas, maka yang menjadi tujuan penelitian ini adalah: Untuk mengetahui hasil karya kerajinan miniatur kapal pada pengrajin kriya Asmidar di Medan Perjuangan. Untuk mengetahui adanya penerapan nilai estetis pada karya kerajinan miniatur kapal pada pengrajin kriya Asmidar di Medan Perjuangan.

\section{Manfaat Praktis}

Sebagai sumber informasi tentang proses pembuatan karajinan miniatur kapal. Sebagai penambah pengetahuan terhadap nilai estetis kerajinan miniatur kapal. Mendorong para perajin dalam meningkatkan kualitas baik variasi bahan dan jenis kerajinan miniatur serta kuantitas kerajinan miniatur yang diproduksinya.

\section{Manfaat Teoritis}

Sebagai bahan pengembangan kepustakaan Jurusan Pendidikan Seni Rupa Fakultas Bahasa dan Seni Universitas Negeri Medan. Sebagai bahan refrensi tentang ragam dan seni kerajinan yang dapat menjadi pembelajaran bagi penulis maupun pembaca.

\section{KAJIAN TEORI}

\section{Analisis}

"Analisis adalah penyelidikan terhadap suatu peristiwa (karangan, perbuatan, dan sebagainya) untuk mengetahui keadaan yang sebenarnya (sebabmusabab, duduk perkaranya, dan sebagainya); proses pencarian jalan keluar (pemecahan masalah) yang berangkat dari dugaan akan kebenarannya; penyelidikan terhadap suatu peristiwa untuk mengetahui keadaan yang sebenarnya" (KBBI, 2007: 43).

Menurut Sugiyono (2016: 335) Analisis adalah proses mencari dan menyusun secara sistematis data yang diproleh dari hasil wawancara, catatan lapangan, dan dokumentasi, dengan cara mengorganisasikan data kedalam kategori, menjabarkan kedalam unit-unit, menyusun kedalam pola, memilih maka yang penting dan yang akan dipelajari, dan akan membuat kesimpulan sehingga mudah dipahami oleh diri sendiri maupun orang lain.

Selain itu, menurut Soemarjadi dkk (1991/1992 :9), analisis adalah kemampuan menguraikan atau menjabarkan sesuatu kedalam bagian -bagian sehingga hasilnya dapat dimengerti. Rumusan tujuan instruksional dapat dinyatakan antara lain dengan kata-kata operasional berikut: dapat membandingkan, mempertentangkan, menyisihkan, menunjukkan hubungan, membuat diagram dan sebagainya.

\section{Kerajinan}

Kerajinan adalah hal yang berkaitan dengan buatan tangan atau kegiatan yang berkaitan dengan barang yang dihasilkan melalui keterampilan tangan (kerajinan tangan). Wikipedia menjelaskan bahwa "seni kerajinan adalah sebutan bagi suatu benda hasil karya manusia". Kata kerajian berasal dari kata rajin yang artinya benda yang dihasilkan oleh keterampilan tangan. Kerajinan terbuat dari berbagai bahan. Dari kerajinan ini menghasilkan hiasan atau benda seni maupun barang pakai. Biasanya istilah ini diterapkan untuk cara tradisional dalam membuat sesuatu.

Menurut Sembiring (2011: 34) dalam Buku Wawasan Seni menyebutkan:

"Seni kerajinan adalah cabang seni rupa yang pewujudan hasil jadinya sangat memerlukan kekeriyaan (craftsmanship) yang tinggi. Seni kerajian juga sering diartikan sebagai seni " pekerjaan tangan"( handcraft)". 


\section{Gorga Jurnal Seni Rupa \\ Volume 07 Nomor 02 \\ p-ISSN: 2301-5942 | e-ISSN: 2580-2380}

Menurut Alwi Hasan, (2001:992). "Kerajinan berasal dari kata "rajin" mendapat awalan ke- dan akhiran -an, dimana kerajinan disini bersifat melatih diri ke arah rajin (gerakan aktif). Gerakan aktif tersebut sudah bisa dikerjakan sejak kecil baik sengaja maupun tidak sengaja, sebagai contoh: anyaman, potong-potongan pakaian, melipat-lipat kertas, mengukir kayu, batu, logam, gading, batik, dan sebagainya, gerakan ini bersifat aktif. Seni suatu usaha untuk membuat seni kerajinan sebagai sarana untuk memperindah berbagai macam alat-alat kebutuhan hidup yang beraneka ragam Usaha pembuatan barang-barang kerajinan manusia menggunakan alat-alat sederhana dan menggunakan ketrampilan tangan manusia dan sifatnya tradisional yang merupakan warisan turuntemurun. Hal ini dapat dilihat dalam pembuatan barang-barang kerajinan yang sudah ada sejak zaman prasejarah, dimana dahulu manusia menggunakan alat-alat sederhana hingga sekarang masih ada dan berkembang terus mengikuti kemajuan zaman ".

Adapun Pengertian kerajinan menurut Kusnadi (1983:11) adalah sebagai berikut:

"Seni kerajinan menurut kata harfiahnya dilahirkan dari sifat-sifat rajin manusia.Namun harus kita sadari bahwa titik berat dari penghasilan dan pembuatan seni kerajinan, bukanlah dikarenakan dari sifat rajin manusia (sebagai lawan dari kata malas), melainkan lahir dari kata terampil atau keprigelan (Jawa) tangan kita. Keterampilan ini didapat dari pengalaman dengan tekun bekerja saja yang dapat meningkatkan cara atau teknik penggarapan serta memperdalam hasil kualitas kerja seseorang yang akhirnya memiliki skill atau keahlian bahkan kemahiran dalam suatu profesi tertentu (craftmanship)".

\section{Miniatur}

Kata miniatur berasal dari kata dasar mini yang memiliki arti kecil atau sesuatu yang berukuran kecil (skala). Miniatur adalah potret atau lukisan dan patung berukuran kecil yang dibuat di atas berbagai permukaan dengan aneka ragam bentuk. Pendapat tersebut didasari oleh pernyataan Ralp Mayer yang menyatakan bahwa, pada awalnya kata miniatur pernah berarti karya lukisan yang menggunakan warna merah (lead/mercuric sulfide/minium), dari kata minium kemudian diturunkan menjadi kata miniatur (Susanto, 2002:74). Sedangkan pengertian miniatur secara umum menurut Poerwadarminta dalam KBBI (1993:584) adalah : "Tiruan sesuatu dalam ukuran yang sangat diperkecil. Pada perkembangannya kata miniatur lebih sering diartikan sebagai tiruan suatu benda yang berbentuk lebih kecil dari wujud aslinya. Sehingga dapat disimpulkan bahwa karya miniatur tidak hanya digunakan untuk memberikan arti terhadap karya lukisan atau dua dimensi saja, namun digunakan pula pada tiruan benda tiga dimensi yang dibuat dalam ukuran kecil".

Dalam ilmu hayat (Soedarso, 1990:28) mengatakan bahwa: Faktor terpenting dalam membuat miniatur dari tiruan sebuah benda adalah pertimbangan aspek skala, pada umumnya perbandingan ukuran skala sebuah miniatur jauh lebih kecil dari ukuran benda nyata. Hasil dari penentuan skala pada suatu karya maupun gambar, dapat kita jumpai pada sebuah gambar peta atau gambar denah sebuah bangunan.

\section{Bambu}

Bambu adalah tanaman jenis rumput-rumputan dengan rongga dan ruas di batangnya. Bambu memiliki banyak tipe. Nama lain dari bambu adalah buluh, aur, dan eru. Di dunia ini bambu merupakan salah satu tanaman dengan pertumbuhan paling cepat. Karena memiliki sistem rhizoma-dependen unik, dalam sehari bambu dapat tumbuh sepanjang $60 \mathrm{~cm}$ (24 Inchi) bahkan lebih, tergantung pada kondisi tanah dan klimatologi tempat ia ditanam (https://id.wikipedia.org/wiki/Bambu).

\section{Miniatur Kapal}

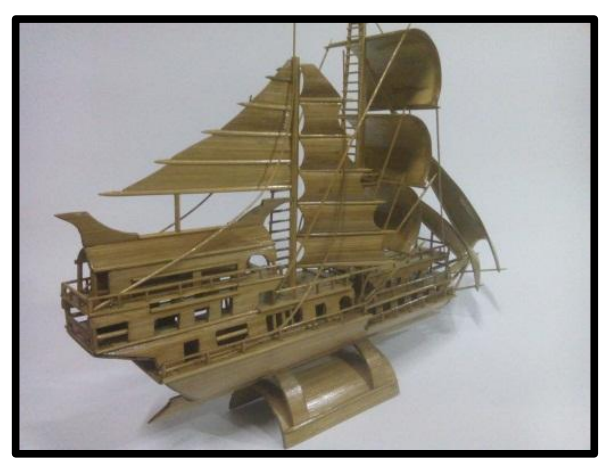

Gambar. 1. Miniatur Kapal

(Sumber: https://www.rumahmesin.com/kerajinan-tangandari-bambu/)

\begin{abstract}
6.Estetika
Estetika adalah salah satu cabang filsafat yang membahas keindahan. Estetika merupakan ilmu membahas bagaimana keindahan bisa terbentuk, dan bagaimana supaya dapat merasakannya. Pembahasan lebih lanjut mengenai estetika adalah sebuah filosofi yang mempelajari nilai-nilai sensoris yang kadang dianggap sebagai penilaian terhadap sentimen dan rasa. Estetika merupakan cabang yang sangat dekat dengan filosofi seni.
\end{abstract}

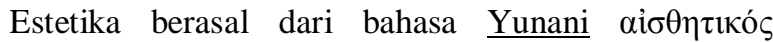
(aisthetikos, yang berarti "keindahan, sensitivitas, kesadaran, berkaitan dengan persepsi sensorik"), yang mana merupakan turunan dari $\alpha i \sigma \theta \alpha ́ v o \mu \alpha \imath$ (aisthanomai, yang berarti "saya melihat, meraba, merasakan"). Pertama kali digunakan oleh filsuf Alexander Gottlieb Baumgarten pada 1735 untuk pengertian ilmu tentang hal yang bisa dirasakan lewat perasaan (https://id.wikipedia.org/wiki/Estetika).

Menurut Dermawan Sembiring (2013:112) estetika juga sering dipadankan dengan teori cita rasa. Dan Alexander Gottlieb Baumgarten memahami estetika sebagai 'pengetahuan tentang yang indah (the science of beautiful). 


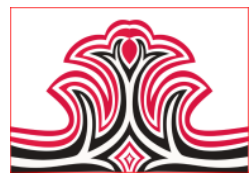

7.Penilaian Pembuatan Kerajinan Miniatur Kapal 1).Proporsi

Proporsi adalah perbandingan antara panjang dan lebar atau tinggi sehingga perbedaan dari perubahan proporsi sering terlihat menyimpang.

\section{2).Keseimbangan}

Menurut Sukimin (2008:43) "keseimbangan adalah menata unsur dengan seimbang antara bagian satu dengan lainnya". Kusrianto (2006:38) mengatakan "Keseimbangan atau balance merupakan prinsip dalam komposisi yang menghindari kesan berat sebelah atas suatu bidang atau ruang yang diisi dengan unsur-unsur rupa".

\section{3).Kesatuan}

Menurut Sukimin (2008:44) prinsip kesatuan adalah penataan unsur dengan menggabungkan unsur menyebabkan diperolehnya hubungan kuat dan erat. Akibatnya ada ketergantungan antar unsur. Kehadiran setiap unsur sangat diperlukan untuk menyatukan.

\section{4).Finishing}

Penilaian selanjutnya adalah Finishing hasil karya kerajina miniatur kapal tersebut. Finishing adalah sentuhan akhir ( sentuhan jamak) perubahan terakhiir, penambahan atau hiasan yang berfungsi untuk menyelesaikan sesuatu (http: kamusinternasional.com/definitions/?indonesiaword=finishin gtouch). hal- hal yang diperhtikan dalam pengambilan nilai finishing adalah meresapnya cat pada permukaan kapal, serta kapal di vernis dan di plitur dengan rapi.

\section{METODE PENELITIAN}

Penelitian dilakukan di pengerajin Kriya Asmidar yang berada di Jalan Ibrahim Umar Medan Perjuangan. Penelitian ini dilakukan selama dua bulan. populasi pada penelitian ini adalah 8 buah kapal. Dengan jumlah sampel 8 buah karya miniatur kapal.

\section{Instrumen Penelitian}

Instrumen penelitian ini terdiri dari:
1. Catatan
2. Kamera
3. Daftar gambar

\section{Teknik Pengumpulan Data}

teknik pengumpulan data penelitian ini yaitu:
1. Dokumentasi
2. Observasi (pengamatan)
3. wawancara

\section{Teknik Analisis Data}

Teknik analisis data yang digunakan dalam penelitian ini adalah teknik analisis data kualitatif.

\section{Gorga Jurnal Seni Rupa \\ Volume 07 Nomor 02 \\ p-ISSN: 2301-5942 | e-ISSN: 2580-2380}

\section{HASIL DAN PEMBAHASAN}

Berdasarkan data yang telah diambil dari tabel penilaian, maka semua hasil penilaian dari ke dua ahli secara keseluruhan pada kerajinan miniatur kapal karya pengerajin Kriya Asmidar ditinjau berdasarkan aspek proporsi, keseimbangan, kesatuan, dan finishing, secara umum dikategorikan baik dengan jumlah rata-rata $=88$ (baik). Penilaian yang lebih tinggi terdapat pada aspek kesatuan dengan nilai ratarata $=89$ (baik), sementara pada aspek finishing dengan nilai $=88$ (baik), selanjutnya diikuti dengan prinsip proporsi dengan nilai $=87$ (baik), dan terakhir aspek keseimbangan dengan nilai $=86$ (baik).

\section{KESIMPULAN DAN SARAN}

\section{Kesimpulan}

Kemampuan siswa dalam menerapkan unsur garis, bentuk, gelap terang, tekstur, ruang/volume pada karya gambar bunga Mawar di kelas VII-5 SMP Negeri 36 Medan rata-rata mencapai nilai (67) dan termasuk dalam kategori Cukup Baik dan 2.Kemampuan siswa dalam menerapkan proporsi pada karya gambar bunga Mawar di kelas VII-5 SMP Negeri 36 Medan rata-rata mencapai nilai (64) dan termasuk dalam kategori Kurang Baik.

\section{Saran}

Berdasarkan hasil analisis data penelitian, maka dapat ditarik kesimpulan sebagai berikut:

1. Secara keseluruhan tingkat kualitas kerajinan miniatur kapal karya pengerajin Kriya Asmidar ditinjau berdasarkan aspek proporsi, keseimbangan, kesatuan, dan finishing, secara umum dikategorikan baik dengan jumlah nilai = 703 dan rata-rata $(r)=88$ (baik).

2. Secara keseluruhan kerajinan miniatur kapal karya pengerajin Kriya Asmidar ditinjau berdasarkan aspek proporsi memperoleh nilai $=702$ dengan rata-rata $(r)=87$ (Baik)

3. Secara keseluruhan kerajinan miniatur kapal karya pengerajin Kriya Asmidar ditinjau berdasarkan aspek keseimbangan memperoleh jumlah nilai $=$ 695 dengan rata-rata (r) $=86$ (Baik).

4. Secara keseluruhan kerajinan miniatur kapal karya pengerajin Kriya Asmidar ditinjau berdasarkan Aspek kesatuan memperoleh jumlah nilai $=710$ dengan rata-rata $(r)=89$ (Baik).

5. Secara keseluruhan kerajinan miniatur kapal karya pengerajin Kriya Asmidar ditinjau berdasarkan Aspek finishing memperoleh jumlah nilai $=705$ dengan rata-rata $(r)=88$ (Baik).

Berdasarkan pembahasan dan kesimpulan dari hasil penelitian, maka peneliti memberikan beberapa saran sebagai berikut :

1. Sebelum menciptakan karya kerajinan miniatur kapal hendaknya lebih baik pengerajin memahami aspek proporsi, keseimbangan, kesatuan, dan finishing, sehingga ketika dalam 
proses pembuatan pengerajin mempunyai landasan untuk menciptakan karya baik.

2. Pengalaman bekarya sangat menentukan hasil akhir dari karya kerajinan miniatur kapal, maka dari itu untuk mencapai tingkat keberhasilan yang baik perlu banyak berlatih.

3. Diharapkan banyak melihat dan mengamati karya kerajinan miniatur kapal sehingga mampu membedakan antara karya yang baik dan tidaak baik.

Harapan penulis hendaknya penelitian ini dilanjutkan dan dikembangkan pada ruang lingkup yang lebih luas sehingga dapat memberikan manfaat yang berarti baik bagi pengerajin sendiri, lingkungan sekitar maupun kedunia pendidikan.

\section{DAFTAR RUJUKAN}

Alwi, Hasan. 2001. Kamus Besar Bahasa Indonesia. Jakarta: Balai Pustaka.

KBBI. 1996. Kamus Besar Bahasa Indonesia Edisi Ke - 2, Jakarta : Balai Pustaka Jakarta.

2005. Kamus Besar Bahasa Indonesia Edisi $\mathrm{Ke}-3$, Jakarta : Balai Pustaka Jakarta.

Kusnadi. 1983. Peranan Seni Kerajinan (Tradisional dan Baru) dalam Pembangunan. Yogyakarta: Kanisius.

Pratama Yuda dan Mutmainah Siti. 2015. Nilai Estetika Kerajinan Cangkang Kerang UD. Baru Senang (Halik Mawrdi) Panarukan Situbondo. Jurnal Seni Rupa UNESA. Vol 3, No 1 .

Sembiring, Dermawan,Triyanto, R, \& Namawi, M. 2011. Wawasan seni. Medan FBS.UNIMED

Soedarso, SP. 1975. Prospek Pengembangan Desain Produk Dalam Industri Ditinjau Dari Segi Estetis. Yogyakarta: Paper, STSRI

Soemarjadi : Ramanto, Muzni : Zahri, Wikdati. 1991. Pendidikan Keterampilan. Departemen Pendidikan Dan Pebudayaan Direktorat Jenderal Pendidikan Tinggi Proyek Pembinaan Tenaga Kependidikan.

Susanto. Mikke (2011). Diksi Rupa Yogyakarta. Dicti Art.......1967. Encyclopedia of World Art Vol. XII New York, 107.

Sugiono. 2016. Metode Penelitian Kuantitatif, Kualitatif, dan R\&D. Jakarta: Alfabeta.

Sukimin, Aw, dan Sudantur, Edy. 2012. Seni Rupa Untuk SMP. Solo: PT. Tiga Serangkai Pustaka Mandiri.

\section{SUMBER INTERNET}

https://id.wikipedia.org/wiki/Bambu hitam

https://id.wikipedia.org/wiki/Estetika

https://manfaat.co.id/manfaat-bambu

https://manfaat.co.id/manfaat-bambu

https://www.rumahmesin.com/kerajinan-tangan-dari-

$\underline{\text { bambu/ }}$ 